\title{
Dental Dosage Form
}

National Cancer Institute

\section{Source}

National Cancer Institute. Dental Dosage Form. NCI Thesaurus. Code C69059.

An substance intended for use on the teeth or gingiva in the oral cavity. 